\title{
METHODOLOGY FOR THE ESTABLISHMENT OF PHYSICAL AND GEOMETRIC PROPERTIES OF A DRAINAGE BASIN
}

\author{
P. Pelikán, M. Šlezingr
}

Received: February 16, 2011

\begin{abstract}
PELIKÁN, P., ŠLEZINGR, M.: Methodology forthe establishment of physical and geometric properties of a drainage basin. Acta univ. agric. et silvic. Mendel. Brun., 2011, LIX, No. 6, pp. 265-270

Factors which affect runoff are closely related to properties of the basin from which the water flows and its environment. They have an effect not only on the size of the runoff but also its origination and mainly its temporal distribution. These factors can be divided into two main groups. The first group contains climatic factors, which are besides precipitation meteorological quantities affecting the overall evaporation of water in the drainage basin. These include the actual temporal and spatial progress of a rainfall, the moisture of air, evaporation, air temperature, the velocity and direction of wind, atmospheric pressure, etc. The other group consists of geographic factors of the drainage basin, which describe the environment in which the process of runoff occurs.

The presented study focuses on a theoretical analysis of physical and geometric properties of a basin, the practical methods and the possible ways of their determination and possible uses of results. In the past the determination of physical a geometric watershed attributes had been working out on the basis of analogue maps. These methods were very labour-intensive and lengthy. The report deals with new determination methods based on digital data processing - utilization of digital terrain model (DTM). These problems are quite actual because of research of rainfall-runoff process, flood process and soil erosion within watershed.
\end{abstract}

digital terrain model, drainage basin, hydrology, physical and geometric factors, rainfall-runoff process

Hydrology is a science which consistently deals with natural principles of water and its cycle. Its significance follows from the irreplaceable character of water for all living creatures, for life and activities of human beings. The knowledge obtained within the field concerning water sources, the origination and distribution of drainage of water on and under the earth surface can be used to enhance the living conditions on the Earth. Hydrological data, which include important characteristics of the hydrological regime, serve mainly as a foundation for proposals of economical and functional water management works and for planning of potential water management interferences improving the hydrological situation.

The need for and the consumption of water is still rising. However, with respect to its limited volume, it is necessary to plan the needs of a society so that water resources for various purposes are used rationally and in the optimum way. The general controlling and concept-making role is in the hands of water management. Its activity is practically impossible without good and reliable hydrological data.

Engineering hydrology provides data and information necessary for design and construction activities and the operation and maintenance of water management works. Besides, it is used in all activities aimed at retaining of the existing good environment or possible improvement of the already damaged environment of a specific area (Starý, 2005). 


\section{METHODOLOGY}

The basic work unit in hydrology is a drainage basin. This is an area from which all water converges to a single point in the stream (ending profile), i.e. this is the drainage area of a stream. This concerns all runoff - surface and groundwater, while the surface runoff usually prevails. When analysing surface runoff, we establish the basin by finding the area within which the water flows from the highest points to lower ones according to the shape and the height topography of the territory. The border of a basin is called water divide and it is a full line going orthogonally to contour lines along the highest points and separating the areas from which water flows towards neighbouring streams. A drainage basin established in this way is an orographic basin (Starý, 2005).

However, it is not always advisable to neglect the difference between the area of an orographic basin and a groundwater basin. Then it is necessary to work with the real, hydrological basin, which is the area of the entire runoff from the drainage basin. Its delineation can present some difficulties, especially in a territory with an occurrence of karst phenomena.

The ending profile has to be set on the stream to delimit the drainage basin. Without this, we always consider the basin of an entire stream down to its mouth.

The factors which affect the runoff are closely related to properties of the basin from which the water flows and its environment. They have an effect not only on the size of the runoff but also its origination and mainly its temporal distribution (fluctuation, changes). These factors can be divided into two main groups. The first group contains climatic factors, which are besides precipitation meteorological quantities affecting the overall evaporation of water in the drainage basin. These include the actual temporal and spatial progress of a rainfall, the moisture of air, evaporation, air temperature, the velocity and direction of wind, atmospheric pressure, etc. The other group consists of geographic factors of the drainage basin, which describe the environment in which the process of runoff occurs. They determine the dynamic (transfer) properties of the drainage basin and thus the way in which the temporal process of a rainfall with the specific spatial distribution will transform into the temporal process of water runoff through the ending profile. This group contains physical and geometric factors, geological properties of the basin, vegetation cover and the river network. Our attention will focus on the physical and geometric factors, the sources of data and the methods for their establishment and their significance for activities within the drainage basin.

The traditional sources of data concerning physical and geometric properties of a drainage basin are analogue hydrological maps with 1:50 000 scale, the basic map of the Czech Republic
1:10 000 (BM 10) and the state map 1:5 000 (SM5). These maps are nowadays available in digital form as well. The Czech Office for Surveying, Mapping and Cadastre provides data in the basic geographic database ZABAGED. This is a digital geographic model of the territory of the Czech Republic, whose accuracy and level of detail of the geographic reality corresponds to the accuracy and level of detail of BM 10. It contains 106 types of geographic objects which are included in the database by means of their vector locations and appropriate descriptive and qualitative attributes. The data also include aerial photos of the territory, selected data on geodetic and elevation points and elevation data represented by a spatial data file of 3D contour lines. The data are provided on individual map sheets in the BM 10 layout, in S-JTSK, WGS84/UTM, S-42/1983 coordinate systems and the 'Baltic After Balancing' elevation reference system. The data can be exported in dgn, shp, gml and mdb formats so that they can be processed in geo-information systems (e.g. Autodesk Map 3D, ESRI ArcGIS, GRASS).

For computer processing of data, we worked with the AutoCAD Civil 3D software by Autodesk, which was examined for its usability in basin analyses. This is a complex application for processing and administration of projects and supports a wide range of civil engineering tasks. The program code uses an object-oriented architecture. As a result, there are dynamic bonds between the entities in the drawings and these keep the intelligent objects updated after each modification. Before the tools of the application can be used, a three-dimensional interpretation of the surface - a digital model of terrain (DMT) - has to be created. For the creation, a wide range of input data can be used, including many drawing objects (3D curves representing contour lines, 3D surfaces, lines, blocks, texts). For specific constructions this will usually be geodetic surveying of the area and the resulting geographical location and altitudes of particular points in the terrain. When the demands concerning accuracy are lower, also the data of the global positioning system (GPS) can be used. The ZABAGED data or digital elevation models (DEM) can be used for an analysis of larger territorial units. However, the interpretation and the degree of reliability of the DMT will always correspond to the quality of the input data, their processing and the purpose for which they have been collected. The software is not designed for complicated analyses of spatial data primarily but it includes several tools usable for the determination of basin properties. These are mainly the functions for an analysis of slopes, exposition, hypsometry, runoff and for the determination of a basin water divide.

Physical and geometric factors can be divided into measured and derived properties of the basin. The measured properties include the basin area, the forest area, the maximum and the minimum altitude of the basin, the maximum and the minimum altitude of the stream, the length of all streams in 
I: Physical and geometric properties of the basin, measured

\begin{tabular}{lcc}
\hline \multicolumn{1}{c}{ Property } & Sign & Unit \\
\hline Basin area & $\mathrm{S}_{\mathrm{p}}$ & $\mathrm{km}^{2}$ \\
Forest area & $\mathrm{S}_{\mathrm{pL}}$ & $\mathrm{km}^{2}$ \\
Basin maximum altitude & $\mathrm{H}_{\mathrm{pMAx}}$ & $\mathrm{m} \mathrm{a.s.l}$ \\
Basin minimum altitude & $\mathrm{H}_{\mathrm{pMIN}}$ & $\mathrm{m} \mathrm{a.s.l}$ \\
Stream maximum altitude & $\mathrm{H}_{\mathrm{tMAx}}$ & $\mathrm{m} \mathrm{a.s.l.}$ \\
Stream minimum altitude & $\mathrm{H}_{\mathrm{tMIN}}$ & $\mathrm{m} \mathrm{a.s.l}$ \\
Length of all streams in the basin & $\mathrm{L}_{\mathrm{t}}$ & $\mathrm{km}$ \\
Length of the main stream & $\mathrm{L}_{\mathrm{ht}}$ & $\mathrm{km}$ \\
Length of valley line & $\mathrm{L}_{\mathrm{u}}$ & $\mathrm{km}$ \\
Spring - ending profile distance & $\mathrm{l}$ & $\mathrm{km}$ \\
Length of watershed divide & $\mathrm{O}_{1}$ & $\mathrm{~km}$ \\
\hline
\end{tabular}

the basin, the length of the main stream, the length of the valley line, the length of the water divide and the direct distance of the spring to the ending profile (Tab. I). As regards derived properties, we establish the middle width of the basin, the basin shape coefficient, the average and the middle altitude, the average slope of the basin, the middle slope of the terrain, the average slope of the stream, the stream irregularity coefficient, forest cover percentage, the density of the river network, the coefficient of basin perimeter articulation, the coefficient of contour line articulation, and the coefficient of terrain articulation (Tab. II).

The maximum and the minimum altitudes are established based on the contour map. Lengths on analogue maps are measured by divider callipers.

II: Physical and geometric properties of the basin, derived

\begin{tabular}{|c|c|c|c|}
\hline Property & Sign & Calculation & Unit \\
\hline Basin middle width & $\mathrm{b}$ & $\frac{S_{p}}{L_{u}}$ & $\mathrm{~km}$ \\
\hline Basin shape coefficient & $\alpha$ & $\frac{S_{p}}{L_{u}^{2}}$ & - \\
\hline Average basin altitude & $\mathrm{H}_{\mathrm{p}}$ & $\frac{H_{p M A X}+H_{p M I N}}{2}$ & m a.s.l. \\
\hline Middle basin altitude & $\mathrm{H}_{\mathrm{ps}}$ & $\frac{s_{1} h_{1}+s_{2} h_{2}+\ldots+s_{n} h_{n}}{S_{p}}$ & m a.s.l. \\
\hline Average slope of basin & $I_{p}$ & $\frac{H_{p M A X}-H_{p M I N}}{\sqrt{S_{p}}} \times 100$ & $\%$ \\
\hline Middle slope of terrain & $I_{\text {ter }}$ & $\frac{I_{1}+I_{2}+\ldots+I_{n}}{n}$ & $\%$ \\
\hline Average slope of stream & $\mathrm{I}_{\mathrm{t}}$ & $\frac{H_{t M A X}-H_{t M I N}}{L_{h t}} \times 100$ & $\%$ \\
\hline $\begin{array}{l}\text { Stream irregularity } \\
\text { coefficient }\end{array}$ & $\mathrm{K}_{\mathrm{n}}$ & $\frac{L_{h t}}{l}$ & - \\
\hline Forest cover percentage & $\mathrm{L}$ & $\frac{S_{p L}}{S_{p}} \times 100$ & $\%$ \\
\hline River network density & $\mathrm{D}$ & $\frac{\sum L_{t}}{S_{p}}$ & $\begin{array}{c}\mathrm{km} \cdot \mathrm{km}^{-2} \\
\mathrm{~m} \cdot \mathrm{ha}^{-1}\end{array}$ \\
\hline $\begin{array}{l}\text { Basin perimeter articulation } \\
\text { coefficient }\end{array}$ & $\mathrm{m}$ & $\frac{O_{1}}{O_{2}}$ & - \\
\hline $\begin{array}{l}\text { Contour line articulation } \\
\text { coefficient }\end{array}$ & $\mathrm{K}_{\check{c ̌ v}}$ & $\frac{D_{\phi v}}{K}$ & - \\
\hline $\begin{array}{l}\text { Terrain articulation } \\
\text { coefficient }\end{array}$ & $\mathrm{K}_{\mathrm{t}}$ & & - \\
\hline
\end{tabular}

Note:

$\mathrm{s}_{1}, \mathrm{~s}_{2}, \ldots, \mathrm{s}_{\mathrm{n}} \ldots \ldots . .$. areas between contour lines

$h_{1}, h_{2}, \ldots, h_{n} \ldots$ average altitudes of contour lines belonging to the areas between contour lines

$\mathrm{O}_{2} \ldots$ circumference of a circle with the area equal to the basin area

$D_{\emptyset_{v}}$.. length of a contour line with the middle altitude together with the section of the watershed divide which connects the points of intersection of the watershed divide with the middle contour line

$\mathrm{K}$.... circumference of the circle with the same area as the area defined by the contour line and a section of the watershed divide 
A length of a stream refers to the distance between the mouth and the spring measured along the stream central line. When measuring the length using an analogue map, it is necessary to keep in mind that streams are pictured on maps in general forms, without any detailed meanders. Therefore, it is necessary to take into account the stream sinuosity and multiply the measured length by a coefficient of 1.01 up to 1.1 to gain the real length (Starý, 2005). The areas on printed maps are generally measured by means of a planimeter, which is a tool working on the basis of a lever mechanism. If digital data and suitable software are available, the establishment of altitudes, lengths and areas is simpler as the individual entities (streams, contour lines, water divides, etc.) contain attributes with properties of analysed objects.

The area of a drainage basin $\left(S_{p}\right)$ is defined as a ground area of the basin projection into a horizontal plane and is expressed in $\mathrm{km}^{2}$. The ground area is then used in the calculation of the other derived properties of a basin.

A natural drainage basin has a shape of a symmetrical or unsymmetrical leaf, more or less elongated. The basin shape with the given temporal and spatial distribution of precipitation determines the creation of flood flows. Basin shape characteristics are the middle width of a basin (b) and the coefficient of basin shape $(\alpha)$. The coefficient of basin shape can be expressed as the ratio between the basin area and a square of length (Starý, 2005). If the values are $0.07-0.24$, the basin is elongated, with values of $0.25-0.50$ the basin is fan-shaped.

The average altitude of the basin can be established by calculation or graphically. The calculation of the average altitude $\left(\mathrm{H}_{\mathrm{p}}\right)$ by means of an arithmetic mean of minimum and maximum attitude values is not very precise. We obtain better information about the altitudes if a hypsometric curve is created. The hypsometric curve is a graphical expression of the relationship between the altitude and the area of the territory lying higher. The hypsometric line is created by placing altitudes of individual contour lines to an axis of line segments, starting from the highest altitudes, and placing the areas to the corresponding lines parallel with y axis in a given scale. By connecting the points a curve is created which provides the minimum and the maximum altitudes of the basin, the total area of the basin is provided by the maximum ordinate and its shape provides an expression of the basin configuration character. The curve also serves for the establishment of the average basin altitude $\left(\mathrm{H}_{\mathrm{ps}}\right)$ - the area defined by the curve and the sections of coordinate axes is measured by planimeter and converted to a rectangle with the same area and the base equal to the maximum ordinate. The edge of the rectangle intersects the axis at the searched altitude. The hypsometric line can be considered a line of excess, i.e. the curve visualising the probability of achieving or exceeding an altitude (Starý, 2005). An alternative solution is the calculation of the middle altitude $\left(\mathrm{H}_{\mathrm{ps}}\right)$, which is based on the same principles of the calculation of areas between contour lines $\left(s_{1}, s_{2}, \ldots, s_{n}\right)$ and the corresponding average contour line altitudes $\left(h_{1}, h_{2}, \ldots, h_{n}\right)$. We can see that the establishment of the average altitude can be highly complicated and time-demanding, mainly in irregular terrain conditions. For computerised processing we can use the tool called Surface analysis and graphically visualise the hypsometry of the digital model of the basin terrain. The application allows us to generate a legend for the hypsometry analysis which also includes the values of real 3D areas defined by the altitudes we established. The middle altitude of the basin model is one of basic features of DMT, therefore, no calculation is necessary.

To establish the average slope of the basin $\left(\mathrm{I}_{\mathrm{p}}\right)$, there are more possible solutions, which differ in laboriousness and the resulting accuracy. The most laborious but highly accurate is a calculation which works with the lengths of contour lines $\left(l_{1}, l_{2}, \ldots, l_{n}\right)$ and their mutual distances (Patočka, Němec, 1956). For this reason, a more simplified relation is used for which only the area and the minimum and the maximum altitudes of the basin have to be known. However, the result is not very accurate and it can be quite different from the real average slope. A more precise method is the establishment of the middle slope of the terrain $I_{\text {ter }}$. For the calculation, the average slopes of lines perpendicular to the contour, distributed evenly along the basin each $500 \mathrm{~m}$ and measured from the valley line to the ridge line, are used. The resulting value is the arithmetic mean of slopes of individual lines perpendicular to the contour. The value of the maximum distance of these lines $(500 \mathrm{~m})$ is set with the aim to guarantee an acceptable information capacity of the result. The lower the distance of the lines, the more accurate result we obtain. If we wanted to ascertain a completely accurate value of the average slope of the basin, we would have to calculate the slopes of the lines with infinitely small distances. This again shows the disadvantageous time-demanding character of the method, or even its unfeasibility, especially for complicated basins with a higher number of partial basins. Therefore, the usage of the DMT of the basin seems to be the most efficient method for the middle terrain slope determination. One of its features is also the provision of the information on the slope angles of the surface. Moreover, the DMT can be used for graphical visualisation of the slopes (map of terrain classification).

The coefficient of the articulation of contour lines $\left(\mathrm{K}_{\mathrm{crV}}\right)$ is established as the ratio between the length of contour line with the middle altitude together with the section of the water divide which connects the points of intersection of the water divide with the middle contour line $\left(\mathrm{D}_{\emptyset_{\mathrm{v}}}\right)$ and the circumference of the circle with the same area as the area defined by the contour line and a section of the water divide (K). 
III: Transport and construction terrain classification (Hrubešová, 1995)

\begin{tabular}{ccr}
\hline Terrain articulation coefficient & Terrain articulation & Optimum density of roads \\
\hline$<2.3$ & flatlands & $\geq 15 \mathrm{~m} . \mathrm{ha}^{-1}$ \\
$2.5-4.0$ & highlands & $\geq 22 \mathrm{~m} . \mathrm{ha}^{-1}$ \\
$\max .4$ & mountains - favourable morphological features & $\geq 19 \mathrm{~m} . \mathrm{ha}^{-1}$ \\
$>4$ & mountains - unfavourable morphological features & $\geq 27 \mathrm{~m} . \mathrm{ha}^{-1}$ \\
\hline
\end{tabular}

If we know the middle slope of the terrain $\left(\mathrm{I}_{\mathrm{ter}}\right)$, the coefficient of contour line articulation $\left(\mathrm{K}_{\check{c v}}\right)$ and the density of river network ( $\mathrm{D}$ in $\mathrm{m} \cdot \mathrm{ha}^{-1}$ ), we can establish the coefficient of terrain articulation $\left(\mathrm{K}_{\mathrm{t}}\right)$. This empirically established value expresses the properties of the terrain by a relative sum of the mentioned hydrological quantities. The resulting value classifies the territory for the purposes of transport and construction terrain classification (Tab. III).

An auxiliary derived property of a basin is the coefficient of the basin perimeter articulation (m). It is established as the ratio between the length of a water divide $\left(\mathrm{O}_{1}\right)$ and the circumference of a circle $\left(\mathrm{O}_{2}\right)$ with an area equal to the area of the analysed basin.

\section{RESULTS}

Nowadays, up-to-date and complex applications are used for the processing of physical and geographic parameters of drainage basins. These applications allow for easy, fast and accurate processing of data with a high quality of result interpretation.

The above-mentioned theoretical analysis of the calculation of drainage basin properties shows that the establishment of some parameters can be highly laborious and time-demanding. When suitable computer technology is used, the results can be further compared, their mutual relationships explored and statistically analysed.

For example, considering the issue of the establishment of a basin area, we arrive at a conclusion that the real area of the terrain differs from the area of the ground projection. With an increasing sloping and terrain articulation, the real $3 \mathrm{D}$ area of the surface increases. It means that if we have a DMT, we are able to determine the deviation of the real area from the area of the projection. Thus we gain a certain area excess which does not appear in the mentioned calculation methods. This increase is in the order of single percents that is why it is usually not considered.

While examining the physical and geometric properties of the Žilůvecký potok basin, we used the data from ZABAGED and the DMT was created in the AutoCAD Civil 3D application. The ground area of the basin was calculated to be $4.199 \mathrm{~km}^{2}$, however, the real area of the 3D surface is $4.332 \mathrm{~km}^{2}$ $\left(\mathrm{I}_{\text {ter }}=19.94 \%, \mathrm{~K}_{\mathrm{t}}=2.997\right)$. The difference between the areas is $133,000 \mathrm{~m}^{2}$, i.e. the deviation is about $3 \%$ of the real area. If we have a slope map, we can find the places with the largest slope and it is these places where the deviation between the ground projection area and the real area will be the highest.

From the perspective of forest access roads construction, the geomorphological parameters affect the necessary density of forest roads for management purposes and thus the economic side of the issue. The basin shape coefficient is significant for roads in the valleys of mountains and highlands. The average altitude of a basin gives information on working conditions as regards the climate. The average slope of the basin and the terrain is related to the difficulty of the construction, financial demands and planning of constructional works. With an increasing slope more soil is needed as the cut and fill slopes are longer. The density of water channels is connected with geological and climatic conditions. The expenses on the construction of forest roads crossing streams increase due to the necessary drainage and construction of culverts and bridges. The higher density of water channels, the more probable is the occurrence of soil erosion. The coefficient of stream irregularity affects the length of valley hauling roads.

\section{CONCLUSION}

Currently, more and more emphasis is laid on the accuracy and swiftness of data processing, high quality of the interpretation of results and their utilization in the decision making process concerning human activities. Hydrology is no exception as its significance and role is determined by the indispensable nature of water. Physical and geometric properties of a drainage basin are the basis for the modelling of the rainfall-runoff process. The establishment of the properties has to be devoted proper attention, and the best available data and the most efficient methods have to be used for their processing and the interpretation of results.

\section{SUMMARY}

The presented study focuses on a theoretical analysis of physical and geometric properties of a basin, the practical methods and the possible ways of their determination and possible uses of results. 
These problems are quite actual because these are related to research of rainfall-runoff process, flood process and soil erosion within watershed.

The report is focused on the methods usable for determination of basin geographical attributes. These ones represent surrounding area in which the rainfall-runoff process is in progress. The geographical attributes involve physical and geometric factors, geological attributes of the basin, vegetation and drainage pattern. The physical and geometric factors influence the dynamic attributes of basin. Hence their correct determination is really important for rainfall-runoff process research in set locality.

In the past the determination of physical a geometric watershed attributes had been working out on the basis of analogue maps. These methods were very labour-intensive and lengthy. In addition the determination exactness was significantly influenced by human factor. The report deals with new determination methods based on digital data processing - utilization of digital terrain model (DTM). Computer data processing was worked out in the AutoCAD Civil 3D software by Autodesk, which was examined for its utilization for basin analyses. This is a complex application for processing and administration of projects and supports a wide range of civil engineering tasks.

The outputs based on the digital terrain model analysis could be used for example on the field of basin water management, erosion control, forest road access, economical planning and construction activities.

\section{REFERENCES}

BAROKOVÁ, D., ŠOLTÉZS, A., 2006: Influence of alternative pumping from snow-up lakes in mountain region on groungwater level regime. In: SIMONA 2006. Simulation,modeling and numerical analysis: Proceedings of the 3rd International Workshop. Liberec, CR, 18.20.9. 2006. Liberec: Technická univerzita v Liberci. ISBN 80-7372-152-X., pp. 7-14.

ČERKAŠIN, A., 1963: Hydrologická příručka. Praha, Státní zemědělské nakladatelství Praha, 215 s.

ČERMÁK, M., 1954: Odtokové poměry malých povodí. Praha, Vodní hospodáŕství, č. 1, s. 9-14, 41-44, ISSN 1211-0760.

HRUBEŠOVÁ, E., 1995: Zpř́istupňování lesa. MZLU Brno.

HRŮZA,P.,2003: Optimisation offorestroadnetwork under principles of functionally integrated forest, Journal of Forest Science, 49 (9), pp. 439-443.

KRAVKA, M., KREJZAR, T., ČERMÁK, J., 1999: Water content in stem wood of large pine and spruce trees in natural forests in central Sweden, Agricultural and Forest Meteorology, 98-99, pp. 555562.

KUPEC, P., 2004: Real potentials of social forest functions of selected forest stands at Zidlochovice Forest Enterprise [Reálné potenciály celospolečenských funkcí lesa vybraných lesních porostů LZ Židlochovice], Journal of Forest Science, 50 (4), pp. 190-198.

PATOČKA, C., NËMEC, J., 1956: Základy hydrologie pro zemědělce a lesníky. Praha, Státní zemědělské nakladatelství Praha, 200 p.

STARÝ, M., 2005: Hydrologie. VUT Brno.

SYNKOVÂ, J., 2009: Possibility of utilization of direction construction in river revitalization [Možnosti využití usměrňovacích staveb v rámci revitalizace toku] (2009) Acta Universitatis Agriculturae et Silviculturae.

ŠLEZINGR, M., 2007: Stabilisation of reservoir banks using an "armoured earth structure", Journal of Hydrology and Hydromechanics, 55 (1), pp. 64-69.

ŠLEZINGR, M., 2010: Bank stabilization of river and reservoir In: People, Buildings and Environment, pp. 419-422, Křtiny 10.-12. 11. 2010, CERM Brno, ISBN 978-80-7204-705-5.

ŠLEZINGR, M., 2010: Functions of Bankside trees and shrubs, In: Rekreace a ochrana př́rody pp. 1719, Krrtiny.

ŠLEZINGR, M., UHMANNOVÁ, H., 2010: Stabilization of banks with using geosynretics, In: People, Buildings and Environment, pp. 547-550, Křtiny 10.-12. 11. 2010, CERM Brno, ISBN 97880-7204-705-5.

ŠOLTÉSZ, A., BAROKOVÁ, D., 2006: Analysis, prognosis and design of control measures of groundwater level regime using numerical modelling. In: Podzemná voda, pp. 113-123, Roč. 12, č. 2, ISSN 1335-1052.

ŠOLTÉSZ, A., BAROKOVÁ, D., HAŠKOVÁ, L., 2007: Optimalizácia vodného režimu na Medzibodroží. In: Acta hydrologica slovaca, p. 173-181, Roč. 8, č. 2, ISSN 1335-6291.

ZELEŇÁKOVÁ, M., 2009: Conference Information: 5th International Conference on River Basin Management, 2009 MALTA Source: RIVER BASIN MANAGEMENT V Book Series: WIT Transactions on Ecology and the Environmen, pp. 15-24, Published: 2009.

ZELEŇÁKOVÁ, M., 2010: Geographical approach to flood risk analysis, In: People, Buildings and Environment, pp. 442-447, Křtiny 10.-12. 11. 2010, CERM Brno, ISBN 978-80-7204-705-5.

Auodesk, Inc., 2009: AutoCAD Civil 3D - User Guide, 2296 p.

Ing. Petr Pelikán, doc. Ing. Dr. Miloslav Šlezingr, Ústav tvorby a ochrany krajiny, Mendelova univerzita v Brně, Zemědělská 1, 61300 Brno, Česká republika, e-mail: pelikanp@seznam.cz, slezingr.m@node.mendelu.cz 